\title{
Maize Landraces as a Source of Adaptation to Climatic Change
}

\author{
Violeta Anđelković · Danijela Ristić · Vojka Babić · Zoran Dumanović · Natalija Kravić
}

Maize Research Institute "Zemun Polje“, Slobodana Bajića 1, 11185 Belgrade, Serbia

\begin{abstract}
Summary: Predictions of global warming point out that frequency and severity of temperature and rainfall extremes are expected to increase in the following decades. Yield stability could be achieved by improvement in future breeding based on information of cereal reproduction under changed environmental conditions. Landraces are valuable sources of beneficial alleles, e.g. tolerance to drought and improved grain yield, for introgression into adapted germplasm. Twenty-six drought tolerant maize landraces, selected among gene bank accessions and previously tested under controlled drought conditions and in temperate climate, were evaluated, at two sites and two plant densities in Zemun Polje. Since 2014 was with enormous rainfalls and flooding, morphological and agronomical traits were measured. Obtained data, together with the results from dry 2012, were plotted for principal component analysis. One local landrace and two introduced landraces, medium in maturity, were selected according to PC analysis and achieved grain yield that was stable across different climatic conditions.

Key words: adaptation, climatic change, drought, landraces, maize, PCA, principal component analysis, tolerance
\end{abstract}

\section{Introduction}

Predictions of global climate lead to water shortage and changes in patterns of precipitation resulting in more frequent, severe and widespread flooding and drought. Climate change also leads to increase of atmospheric $\mathrm{CO}_{2}$ and temperature up to 6 degrees by 2050, and increased presence of pests, diseases and weeds (ESA 2014). According to climate models (Battisti \& Naylor 2009), by the end of this century, temperatures in growing season will be beyond the most extreme temperatures in the 20th century. In addition, distribution of global precipitation will differ spatially and seasonally (Chun et al. 2011).

Drought is projecting to be an increasing problem for agriculture and food production and thus the development of tolerant cultivars is a priority objective. The solution could be evaluation of genetic diversity within gene banks, which hold potential for adaptation to a changing climate. However, breeding for drought tolerance, as polygenic and complex trait, is difficult due to large influence of genotype $\times$ environment on final yield (Nazari \& Pakniyat 2010).

Modern cultivars are almost always genetically homogenous, created to achieve high yield under

Corresponding author:

avioleta@mrizp.rs

Acknowledgements:

This study was supported by Ministry of Education, Science and Technological Development of the Republic of Serbia, through the project TR 31068 "Improvement of maize and soybean traits by molecular and conventional breeding". favourable conditions, but they perform less successfully in high-stress and less favorable areas (Annichiarico \& Pecetti 1998). Generally, landraces have lower yields than commercial varieties or hybrids. However, they are essential in breeding programs, which frequently needs germplasm to develop superior cultivars. Increased utilization of genetic resources and landraces in breeding could improve modern agriculture and conventional breeding. Landraces are genetically heterogeneous, but with high yield stability, due to inter-genotype competition and compensation under varying biotic and abiotic factor (Zeven 1998).

Since maize is the most important crop in Serbia, and drought is seriously affecting final grain yield, identification of accessions from Maize Research Institute gene bank, that performed well and tolerated drought, started in 2007 (Babić et al. 2011, Andjelkovic et al. 2014). After preliminary screening under controlled drought stress in Egypt (140 km south of Cairo) and testing in temperate climate (Zemun Polje and Skoplje, Macedonia), a mini-core collection was established. It comprised 15 inbred lines and 26 landraces (13 local, from former Yugoslavia territory and 13 introduced). A set of landraces were tested in 2012 and 2014 under different density conditions. Performance of drought tolerant landraces in the particular rainfall conditions in 2014 was presented in this paper to distinguish the best accessions, according to morphological traits, grain yield and yield components for further utilization in breeding for upcoming climatic changes. Also, landraces were compared regarding grain yield and morphological traits in 2012 and 2014. 


\section{Materials and Methods}

A total of 26 landraces were evaluated in 2014 in Zemun Polje, Serbia, at two sites in two plant densities. A randomized complete block design (RCBD) with two replications was used in the experiments. The soil was slightly calcareous chernozem with $47 \%$ clay and received the usual compound of mineral fertilizer. Plants were sown in single row plots with 10 hills per row and spaced $0.75 \mathrm{~m}$ apart. Spacing between hills was $30 \mathrm{~cm}$ and $40 \mathrm{~cm}$, respectively. Plots were overplanted and thinned to two plants per hill after seedling establishment. Morphological traits, such as plant height, total number of leaves, leaf length, leaf width and grain yield, were recorded for each entry in two replications, on ten representative plants per experiment. Grain yield was calculated per plant, after manual harvesting and drying to $14 \%$ of moisture content. Grain components: ear length, number of rows per ear, number of kernels per row, ear diameter, cob diameter, kernel length and kernel width, were recorded on ten randomly chosen ears. Correlation analysis was carried out to determine the contribution of the investigated traits to grain yield. The differences among landraces based on morphological traits and grain yield, as well as on grain yield and yield components were evaluated by means of principle component analysis (PCA). PCA was computed using correlation matrix of all the measured traits in each of the treatments. Statistical analysis was performed by using SPSS 15.0 for Windows Evaluation.

\section{Results and Discussion}

There are several studies (Kato 1988, Prasanna 2012) on local maize drought tolerant landraces, such as Tuxpeño Sequía and Bolita that were used in national breeding program. Landraces, as sources of favourable alleles, could be used to improve existing maize germplasm for both grain yield and stability (Menkir et al. 2006) in stressful and favourable growing conditions.

The experiments were carried out in Zemun Polje ( $44^{\circ}$ $52^{\prime} \mathrm{N}, 20^{\circ} 19^{\prime} \mathrm{E}, 81$ m.a.s.l.). In Serbia, maize is the most important crop grown mainly in rainfed conditions. Estimated optimal precipitation for maize growing at the region where the trial was performed is $459 \mathrm{~mm}$ (Vasić \& Kerečki 1988), but besides total amount, distribution during season is very important (Vučić 1991). Figure 1 shows the temperature and precipitation in vegetative period: average for the last 10 year period (2005-2014), for 2012 (with the minimum sum of precipitations of 282.9 $\mathrm{mm}$ in this period) and for 2014 (with the highest sum of precipitation of $873.2 \mathrm{~mm}$ in the last 40 years), as well as estimated optimal amount of rainfalls for growing maize. It is evident that monthly temperatures in 2012 were above 10-year average, particularly in June, July and August. Beside higher temperatures, significant deficit of rainfalls, compared to optimal, was recorded in stated months. Maize flowering and grain filling period (the end of June, July and August in Serbia) are the most sensitive to terminal drought, e.g. the greatest yield reduction occurred if drought coincided with flowering and grain filling (Grant et al. 1989). In 2012, as a consequence of drought, both maize total production and average grain yield in Serbia were reduced by about $48 \%$, compared to the period 2009 2011 (www.stat.gov.rs).

The timing and form of drought changes from year to year, so it is difficult to design open-field experiments with reproducible results, suitable for selection of genotypes with good performance under stress conditions. That is why field trials are set up under various plant densities, where increased number of plants per plot simulates different level of stress.

Higher plant densities increase plant competition for photosynthesis, soil nutrients and water, which result in decreased kernel number and size, as well as in increased bareness (Lemcoff \& Loomis 1994). It is very difficult to breed for adaptability to extreme and variable differences in temperature and rainfalls and to mimic such events in testing environments. As 2014 was the year with enormous amount of rainfalls and flooding (the greatest since measurement started in Serbia), we were able to estimate performance of landraces which were previously chosen as drought tolerant (Andjelkovic et al. 2014).

Breeding programs are based on selection for several traits simultaneously and, therefore, knowledge on the genetic association between them is necessary. Correlations detect the strength of relationships between grain yield and the other examined traits. Although in many studies correlations among maize traits were estimated, there are limited results about landraces. Correlation coefficients among the four plant traits and grain yield were all positive and high (Table 1). Similar relations in maize landraces were detected in the other studies (Bertin \& Gallais 2000, Ferro et al. 2007, Rahman et al. 2015). However, under drought, increased density and other stresses correlations are not very strong (Bänziger et al. 2000, Andjelkovic et al. 2014). Also, grain yield was in very significant correlations with ear traits, that is usual association under favourable conditions (Menkir et al. 2009, Munyiri et al. 2013).

Table 1. Correlation coefficients between grain yield and agronomic traits in chosen maize landraces under different densities (D-30, $30 \mathrm{~cm}$, between hills and D-40, $40 \mathrm{~cm}$ between hills in the row)

\begin{tabular}{lll}
\hline Trait & D-30 & D-40 \\
\hline Plant height & $0.668^{* * *}$ & $0.652^{* * *}$ \\
No. of leaves & $0.659^{* * *}$ & $0.819^{* * *}$ \\
Leaf length & $0.681^{* * *}$ & $0.783^{* * *}$ \\
Leaf width & $0.699^{* * *}$ & $0.703^{* * *}$ \\
Ear length & $0.695^{* * *}$ & $0.796^{* * *}$ \\
No. of rows/ear & $0.645^{* * *}$ & $0.605^{* *}$ \\
No. of kernels/row & $0.628^{* * *}$ & $0.758^{* * *}$ \\
\hline
\end{tabular}

*** - significant at the 0.001 probability level; ** - significant at the 0.01 probability level; 


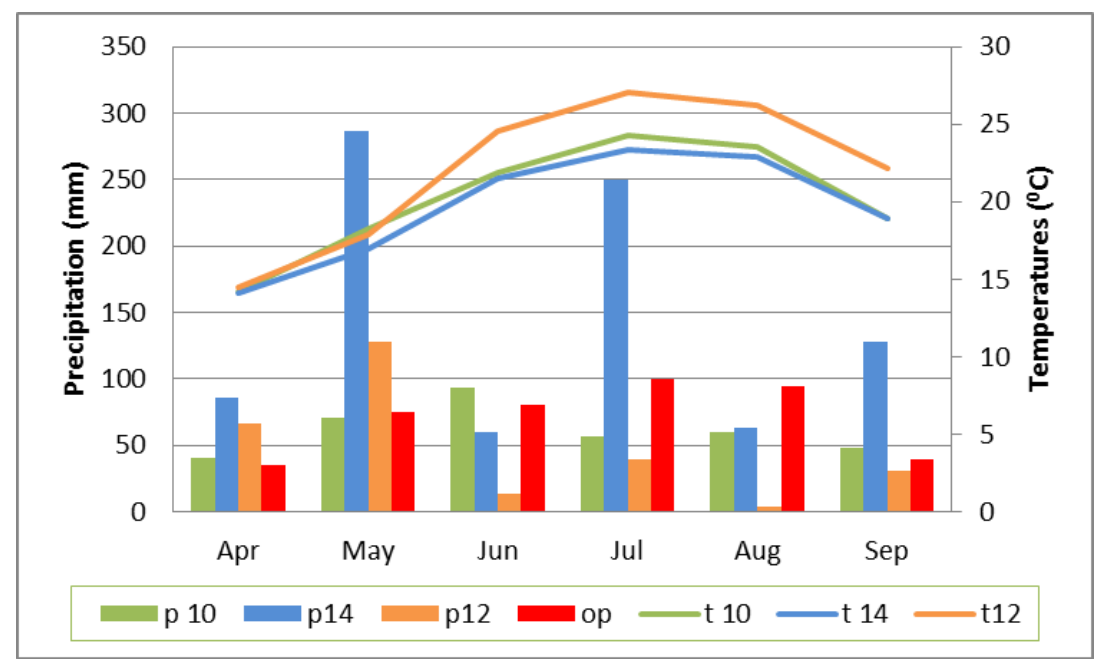

Figure 1. Distribution of rainfalls and average temperatures for growing season in 10-year average period (p-05-14 and t-05-14), 2012 (p-12 and t-12), 2014 (p-14 and t-14), and optimal amount of precipitation (op), according to Vučić (1991)

Although correlation analysis is very useful in presenting overall interrelation between traits, it is not efficient in interpreting performance of individual genotype, which is of high importance in breeding. PCA helps to identify the traits with the highest variability as well as those that characterize the distinctness among selected genotypes. The analysis was performed for grain yield and yield components in both densities. Under D-30 the first PCA explained $49.13 \%$ of total variation, with number of kernel per row, ear length and cob diameter (negative influence) as most relevant traits, which vary together, while the second PCA explained $15.19 \%$ of total variation with number of rows per ear as most important (Fig. 2). The first PCA under D-40 explained $51.96 \%$ of total variation, with number of row per ear and ear diameter as most important traits, while the second PCA explained $13.18 \%$ of total variation, and represent kernel weight, ear length and number of kernels per ear as most important (Fig. 3). Thus, through PCA we could identify traits that are responsible for observed genotypic variation and different distribution of examined landraces. The landraces that are in common according to their performances under well-watered conditions in the open field, and in both applied densities were following numbers: $3,4,7,15,19,21$, and 24 .

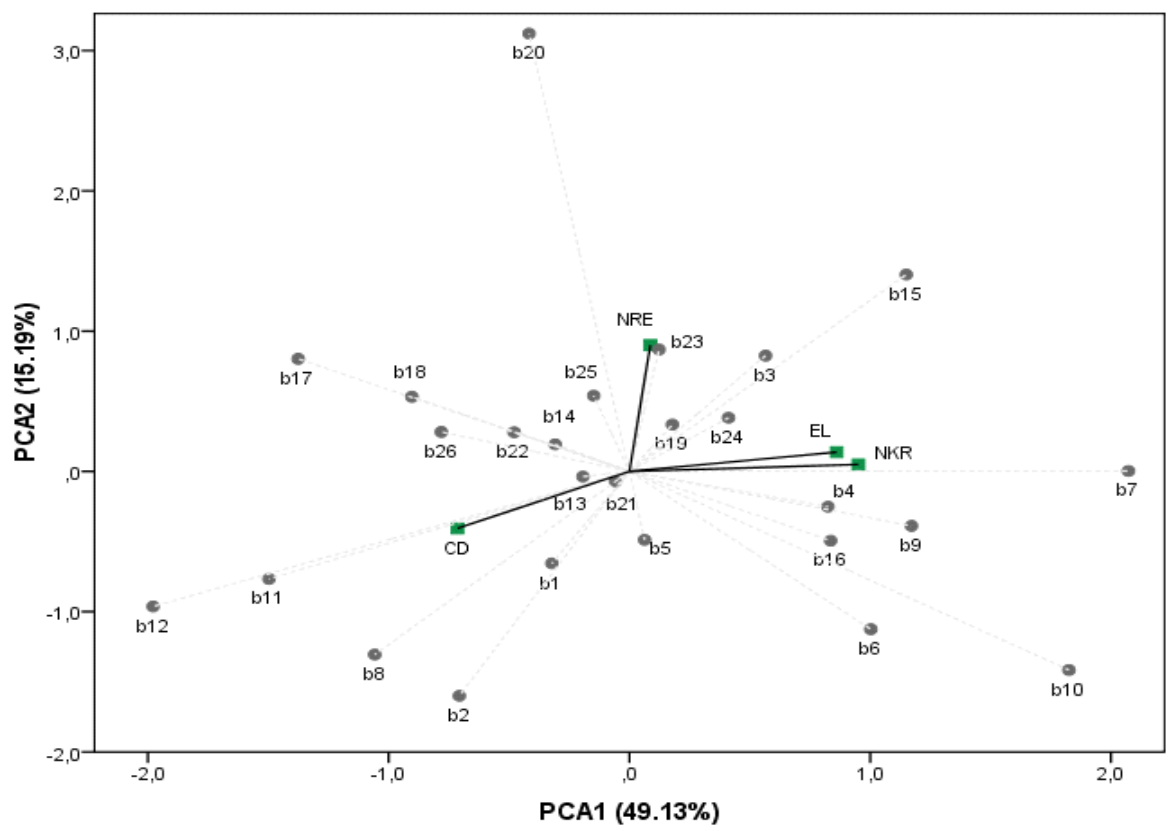

Figure 2. Principal component analysis of maize landraces based on yield components in 2014 in density D-30cm and the most important traits: NKR (number of kernel per row), EL (ear length), CD (cob diameter), NRE (number of rows per ear) 


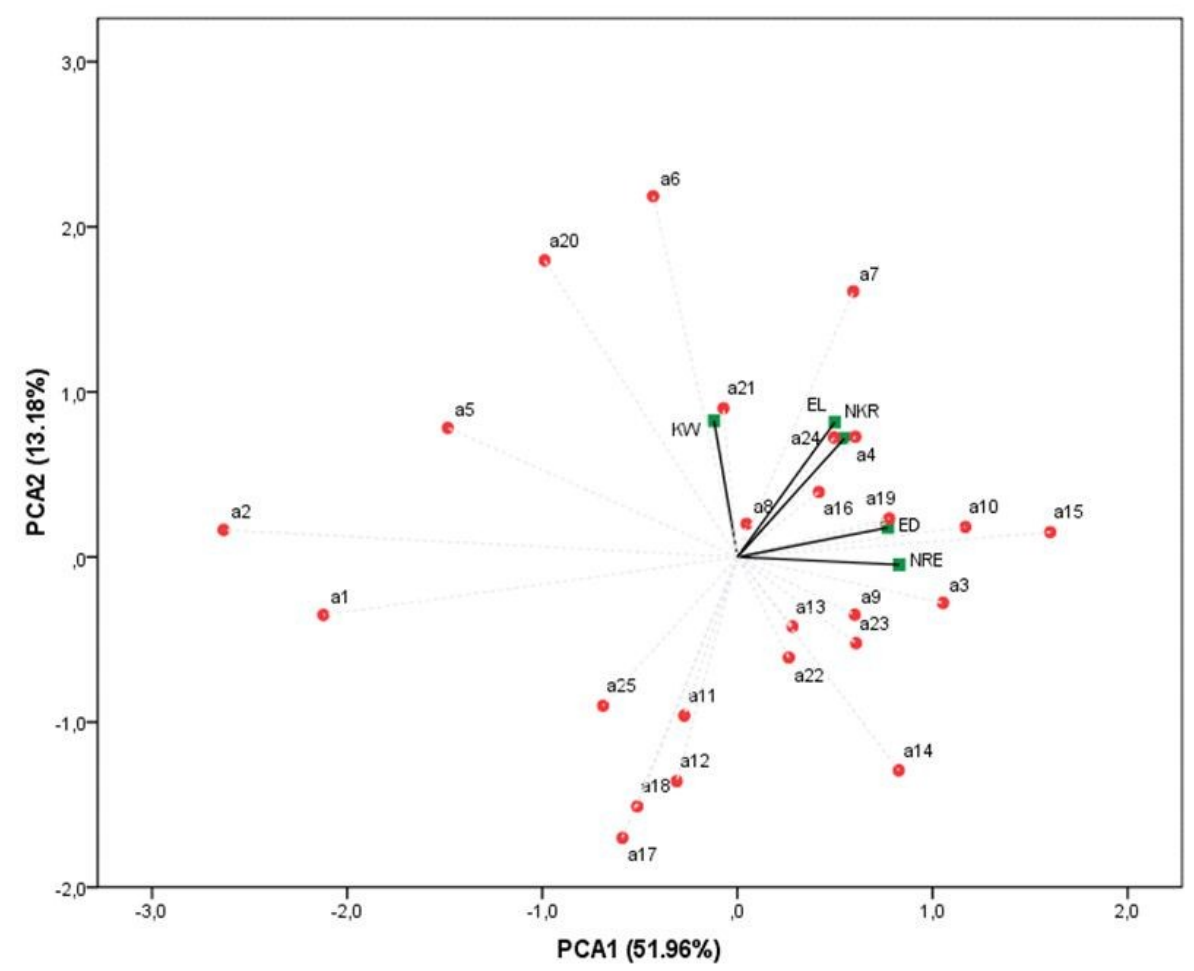

Figure 3. Principal component analysis of maize landraces based on yield components in 2014 in density D-40cm and the most important traits: NRE (number of rows per ear), ED (ear diameter), KW (kernel weight), EL (ear length) and NKR (number of kernels per row)

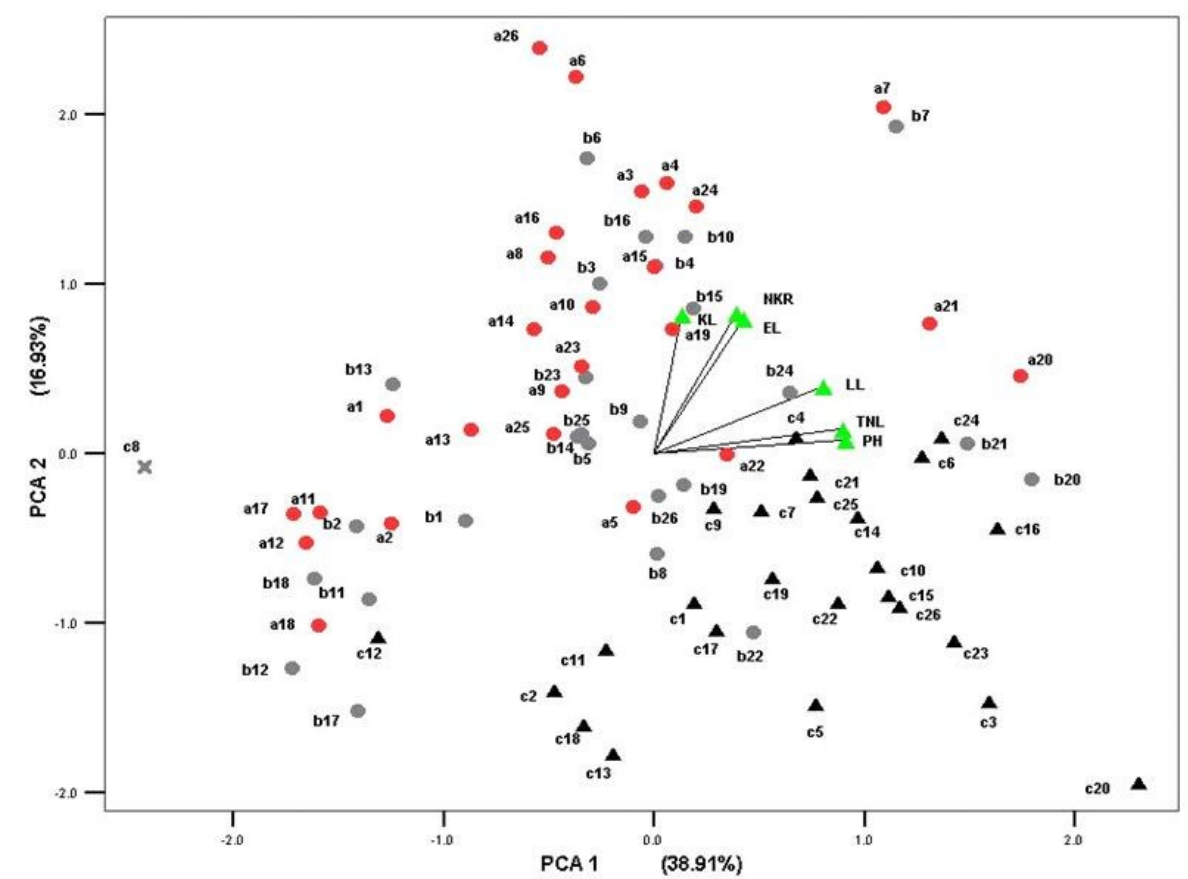

Figure 4. Principal component analysis of maize landraces based on morphological traits and yield components in different environments ( - , D-40 cm in 2014, b - D-30 cm in 2014, c $\boldsymbol{\Delta}$ D-40 cm in 2012) and the most important traits: PH (plant height), TNL (total number of leaves), LL (leaf length), NKR (number of kernels per row), EL (ear length) and KL (kernel length). 


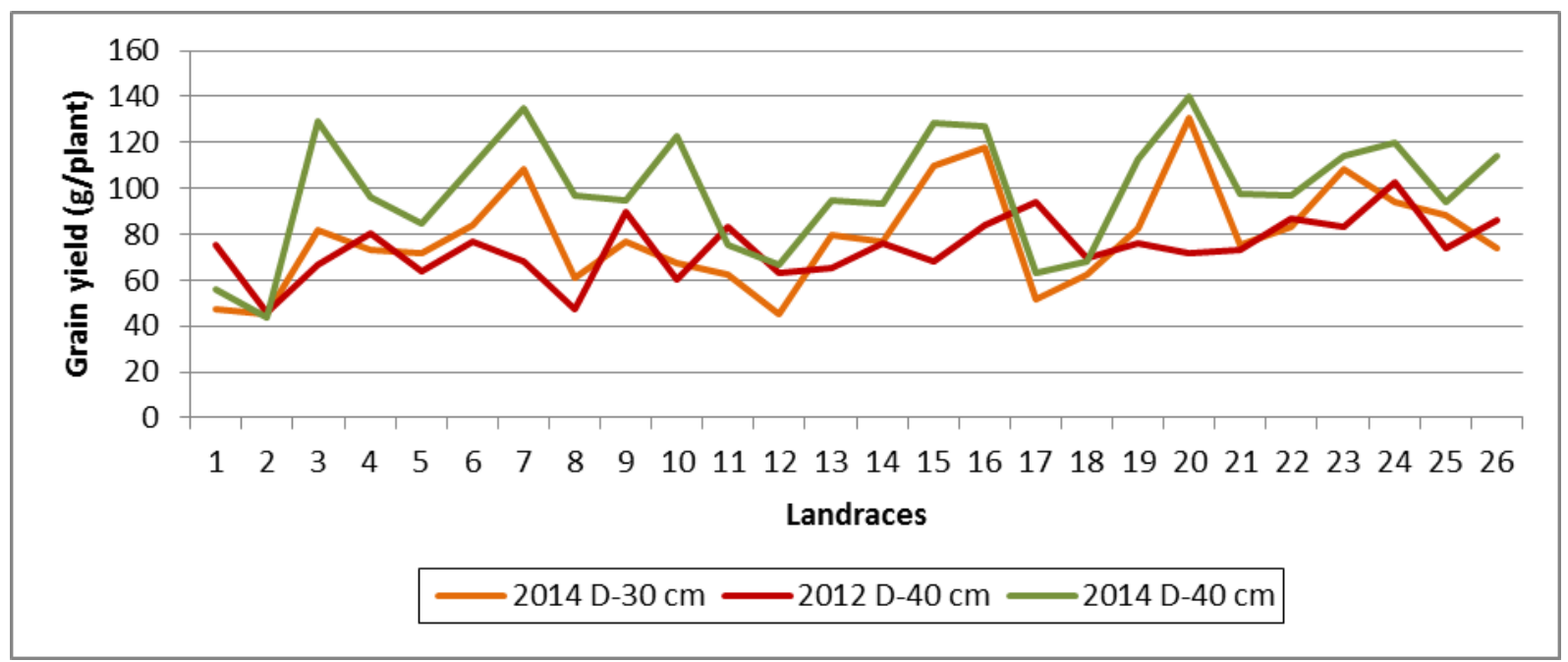

Figure 5. Average grain yield (g/plant) of maize landraces obtained in different climatic conditions (2012 and 2014) and plant densities

Since we had field trials with the landraces from mini -core collection in two years, 2012 (Andjelkovic et al. 2014) and 2014, with the minimum and maximum rainfalls in 10 -years period, we put together all morphological traits, together with yield components (Fig. 4). We used PCA to identify most important traits for characterizing group of landraces for all environmental conditions. Morphological traits (e.g. plant height, total number of leaves and leaf length) were the most important for the first PCA which explained the $38.91 \%$ of the total variation. Plant height, leaf length and number of leaves are in significant correlations with grain yield and are important for assimilate accumulation (Chapman \& Edmeades 1999, Monneveux et al. 2006). Increased number of leaves and greater leaf area increased nutrient uptake, photosynthetic activity and grain yield in various environments (Bänziger et al. 2000). The second PCA explained $16.93 \%$ of total variation with yield components, e.g. number of kernels per row, ear length and kernel length as most important traits.

Based on similar performance under contrary climatic conditions, the landraces 4, 21 and 24 could be separated from the others. They originate from Serbia (4) and USA (21 and 24), are medium in maturity and with dent type of kernel. According to Blum (2011), high yielding potential could be achieved under optimal and mild water stress environmental conditions (e.g. D30 in the present study), but under more severe water stress, only germplasm with specific adaptive genes can maintain stable yield. Genetic variance for yield under stress is low, and selecting the genotypes that tolerate stress on the basis of grain yield alone is not efficient (Bänziger et al. 1997, Betran et al. 2003). Differences between landraces were consistent across environments. The lowest differences for grain yield in density (D-40) in 2012 and 2014, and the highest adaptability showed landraces from Bosnia and Herzegovina 2, 9, 12 and Russia (18, Fig. 5.) Similarly, tolerant maize landrace was always stable, with $14 \%$ higher yield across different combinations of temperature and water stresses compered to sensitive one (Castro-Nava et al. 2014). Considering obtained grain yield in the field the three landraces (4, 21 and 24) had the highest stability in all experimental conditions and can be considered as the most valuable sources of water stress tolerance for application in maize breeding programs.

\section{Conclusions}

Selection of water stress tolerant maize landraces under stress conditions was efficient, since they showed high and stable yield in two years with the highest deficit and excess in rainfalls for maize growing. Majority of them originated from western Balkan area, and showed significant adaptability and stability under different climatic conditions. They can be used as invaluable source material for improving or/and developing parental lines of hybrids that can adapt to variable water stress in unpredictable environmental conditions.

\section{References}

Andjelkovic, V., Kravic, N., Babic, V., Ignjatovic-Micic, D., \& Vancetovic, J. (2014). Estimation of drought tolerance among maize landraces from mini-core collection. Genetika, 46(3): 775788.

Annichiarico, P. \& Pecetti, L. (1998). Yield vs. morphophysiological trait-based criteria for selection of durum wheat in a semi-arid Mediterranean region (northern Syria). Field Crop Res., 59: 163173.

Babić, M., Andjelković, V., Mladenović Drinić, S., \& Konstantinov, K. (2011). The conventional and contemporary technologies in maize (Zea mays L.) breeding at Maize Research Institute Zemun Polje. Maydica, 56: 155-164. 
Battisti, D. S., \& Naylor, R. L. (2009). Historical warning of future food insecurity with unprecedented seasonal heat. Science, 323: 240-244.

Bänziger, M., Betran, F. J., \& Lafitte, H. R. (1997). Efficiency of highNitrogen selection environments for improving maize for low nitrogen target environments. Crop Sci., 37: 1103-1109.

Bänziger, M., Edmeades, G. O., Beck, D., \& Bellon, M. (2000). Breeding for Drought and Nitrogen Stress Tolerance in Maize: From Theory to Practice. CIMMYT, Mexico DF.

Bertin, P., \& Gallais, A. (2000). Genetic variation for nitrogen use efficiency in a set of recombinant maize inbred lines. I. Agrophysiological results. Maydica, 45: 53-65.

Betran, F. J., Ribaut, J. M., Beck, D., \& De Leon, D. G. (2003). Genetic diversity, specific combining ability and heterosis in tropical maize under stress and nonstress environments. Crop Sci., 43: 797-806.

Blum, A. (2011). Plant Breeding for Water-Limited Environments. Springer, New York.

Castro-Nava, S., Ramos-Ortíz, V. H., Reyes-Méndez, C.A., \& Huerta, A.J. (2014). Grain yield, photosynthesis and water relations in two contrasting maize landraces as affected by high temperature alone or in combination with drought. Maydica, 59: 104-111.

Chapman, S. C., \& Edmeades, G. O. (1999). Selection improves drought tolerance in tropical maize populations: II. Direct and correlated responses among secondary traits. Crop Sci., 39: 1315-1324.

Chun, J. A., Wang, Q. G., Timlin, D., Fleisher, D., \& Reddy, V. R. (2011) Effect of elevated carbon dioxide and water stress on gas exchange and water use efficiency in corn. Agric. for Meteorol., 151: 378-384.

ESA (2014). ESA report. Retrieved from: www.seedworld.com.

Ferro, R. A., Brichette, I., Evgenidis, G., Karamaligkas, Ch., \& MorenoGonzalez, J. (2007). Variability in European maize (Zea mays L.) landraces under high and low nitrogen inputs. Genet. Resour. Crop Ev., 54: 295-308.

Grant, R. S., Jackson, B. S., Kiniry, J. R., \& Arkin, G. F. (1989). Water deficit timing effects on yield components in maize. Agron. J., 81: 6165.

Kato, Y. T. A. (1988). Cytological classification of maize race populations and its potential use. In: N Russell, GM Listman (eds.) Recent advances in the conservation and utilization of genetic resources.
Proceedings of the Global Maize Germplasm Workshop. CIMMYT, Mexico D.F. pp. 106-117.

Lemcoff, J. H. \& Loomis, R .S. (1994). Nitrogen and density influences upon silk emergence, endosperm development, and grain yield in maize. Field Crops Res., 38: 63-72.

Menkir, A., Olowolafe, M. O., Ingelbrecht, I., Fawole, I., BaduApraku, B., \& Vroh, B. I. (2006). Assessment of testcross performance and genetic diversity of yellow endosperm maize lines derived from adapted $\mathrm{x}$ exotic backcrosses. Theor. Appl. Genet., 113: 90-99.

Menkir, A., Badu-Apraku, B., Ajala, S., Kamara, A., \& Ndiaye,A. (2009). Response of early maturing maize landraces and improved varieties to moisture deficit and sufficient water supply. Plant Gen. Res., 7(3): 205-221.

Monneveux, P., Sánchez, C., Beck, D., \& Edmeades, G. O. (2006). Drought tolerance improvement in tropical maize source populations: evidence of progress. Crop Sci., 46: 180-191.

Munyiri, S. W., Mugo, S. N., Otim, M., Tefera, T., Beyene, Y., Mwololo, J. K., \& Okori, P. (2013). Responses of tropical maize landraces to damage by Chilo partellus stem borer. Afr. J Biotech., 12(11): 1229-1235.

Nazari, L., \& Pakniyat, H. (2010). Assessment of drought tolerance in barley genotypes. J. Appl. Sci., 10: 151-156.

Prasanna, B. M. (2012). Diversity in global maize germplasm: characterization and utilization. J. Biosci., 37: 843-855.

Rahman, S., Mukul, Md. M., Quddus, T., Hassan, L., \& Haque, Md. A. (2015). Assessing genetic diversity of maize (Zea mays L.) genotypes for agronimic traits. Res. Agric. Livest. Fish., 2 (1): 53-61.

Vasić, G., \& Kerečki, B. (1988). Suša i efekat navodnjavanja na proizvodnju kukuruza. Zbornik radova sa savetovanja o unapređenju proizvodnje i korišćenja kukuruza. Kukuruz 88: 103116.

Vučić, N. (1991). Putevi redukcije magnitude oscilacija prinosa u Vojvodini. Zbornik radova Naučnog instituta za ratarstvo i povrtarstvo, Novi Sad, 9: 5-8.

Zeven, A. C. (1998). Landraces: a review of definitions and classifications. Euphytica, 104: 127-139.

\section{Populacije kukuruza kao izvor adaptabilnosti na klimatske promene}

\section{Violeta Anđelković · Danijela Ristić · Vojka Babić · Zoran Dumanović · Natalija Kravić}

Sažetak: Procenjuje se da će u narednim decenijama, usled globalnog zagrevanja, doći do učestalije pojave ekstremnih temperatura i padavina. Ostvarivanje stabilnih prinosa u budućim programima oplemenjivanja zavisiće od informacija o mogućnostima reprodukcije useva u promenjenim uslovima spoljašnje sredine. Populacije predstavljaju dragocen izvor poželjnih alela (npr. za tolerantnost prema suši i poboljšanje prinosa) za introgresiju u adaptiranu germplazmu. Dvadeset šest populacija kukuruza, tolerantnih na sušu, odabranih iz banke gena i prethodno testiranih u uslovima kontrolisanog stresa suše, kao i u umerenom klimatu, testirane su na dva lokaliteta i u dve različite gustine u Zemun Polju. U 2014. godini koju su obeležile velike količine padavina i poplave, merena su morfološka i agronomska svojstva. Dobijeni podaci, zajedno sa podacima iz sušne 2012. godine obrađeni su PCA metodom (analiza glavnih komponenti). Jedna lokalna i dve introdukovane, srednjestasne populacije, odabrane su na osnovu PC analize i ostvarenog prinosa zrna, koji je bio stabilan bez većih variranja, u različitim uslovima spoljašnje sredine.

Ključne reči: adaptabilnost, analiza glavnih komponenti, klimatske promene, kukuruz, PCA, populacije, suša, tolerantnost 